\title{
Diarrhoeagenic Escherichia coli from routine diagnostic faecal samples in England and Wales
}

There are five established groups of Escherichia coli known to be associated with infectious intestinal disease (IID): verocytotoxin-producing E. coli (VTEC), enteropathogenic E. coli (EPEC), enterotoxigenic E. coli (ETEC), enteroinvasive E. coli (EIEC) and enteroaggregative E. coli (EAggEC) (Kaper et al., 2004). In the UK, VTEC O157 are identified by their inability to ferment sorbitol. However, phenotypically nonO157 VTEC and the other diarrhoeagenic E. coli (DEC) are more difficult to distinguish from non-pathogenic E. coli, and are not detected routinely.

Specific PCRs designed to detect certain pathogenicity genes can be used to identify strains belonging to the five DEC groups. The pathogenicity genes targeted include the verocytotoxin gene $(v t x)$ for the detection of VTEC, the E. coli attaching and effacing gene (eae) associated with EPEC, the heat-stable (ST) and heat-labile toxin genes (LT) for the identification of ETEC, the invasin plasmid antigen gene $(i p a H)$ for EIEC, and the antiaggregation protein transporter gene (aat) for the detection of EAggEC (Kaper et al., 2004).

In 1999, a study of IID in England found that of the five DEC groups, EAggEC were isolated most frequently. Strains of EAggEC were identified in $5 \%$ of faecal samples with a higher incidence of colonization in cases compared to healthy individuals (Tompkins et al., 1999). Subsequent studies supported these data (Amar et al., 2004; Jenkins et al., 2006). The authors of the IID study recommended 'a review of organisms routinely sought in diagnostic laboratories, and that particular consideration should be given to enteroaggregative ... E. coli (FSA, 2000). Strains of EAggEC are characterized phenotypically by their adherence to HEp-2 cells in a stacked brick formation (Nataro et al., 1987). This phenotype is linked to, but not exclusively associated with, the presence of the aat gene (Baudry et al., 1990).

The Gastrointestinal Infections Reference Unit (GIRU) at the Health Protection Agency receives approximately 1600 isolates each year for confirmation of identification of Shigella species, approximately $6 \%$ of these are identified as E. coli. A further 1600 isolates are submitted per annum as VTEC O157, of which approximately $10 \%$ are found to be $v t x$-negative E. coli. The aim of this study was to use PCR to determine whether these strains of $E$. coli harboured the $i p a H$ and aat genes associated with EIEC and EAggEC, respectively.

Between April and September 2009, 85 isolates of $v t x$-negative $E$. coli were identified by GIRU. A total of 44 of these strains were received requesting confirmation or exclusion of VTEC O157 and 41 were submitted requesting confirmation or exclusion of Shigella species. All 85 strains were tested for the presence of ipaH (Sethabutr et al., 1993) and aat (Schmidt et al., 1995; Amar et al., 2005). Of these, 5 were EIEC and 15 were EAggEC (Table 1).

Seven of the EAggEC strains belonged to serogroup O151, two were O62, one was $\mathrm{O} 55$ and five were O-unidentifiable. A search of the GIRU archives showed that over the past 5 years a further 18 strains of E. coli O151 (9) and O62 (9) had been identified. Fourteen of these harboured the aat gene (Table 1). Of the 34 patients from whom EIEC or EAggEC were detected (Table 1), 20 were known to have travelled abroad. The IID study previously showed an association with EAggEC and foreign travel (FSA, 2000).

Twenty-eight of the strains in Table 1 were non-lactose fermenting, although the majority of EAggEC are lactose-fermenting (Barroe \& Feltham, 2003; Scheutz \& Strockbine, 2007). Lactose-fermenting strains are less likely to be sent to the reference laboratory for confirmation or exclusion of Shigella species. Eight of the nine isolates submitted for confirmation or exclusion of VTEC O157 were non-sorbitol fermenting strains. Although there are no routine protocols for the detection of EAggEC in the diagnostic microbiology laboratory in the UK, the results from this study show that this group of putative pathogens may be the cause of IID, especially in cases associated with travel. Microbiology laboratories are increasing their repertoire of molecular assays, and the detection and identification of DEC in the routine diagnostic environment is now possible. Routine detection will help determine the true prevalence of DEC in the UK and identify possible sources of infection and associated risk factors.

\section{Acknowledgements}

We are grateful to Mrs Dawn Hedges and Mrs Carolyn Smith for their excellent technical assistance.

\section{Neil Perry, Claire Jenkins, Tom Cheasty and John Wain}

Gastrointestinal Infections Reference Unit, Gastrointestinal and Emerging Zoonotic Infections Department, Health Protection Agency, Centre for Infections, London NW9 5EQ, UK

Correspondence: Claire Jenkins (claire.jenkins@hpa.org.uk)

Amar, C. F., East, C., Maclure, E., McLauchlin, J., Jenkins, C., Duncanson, P. \& Wareing, D. R. (2004). Blinded application of microscopy, bacteriological culture, immunoassays and PCR to detect gastrointestinal pathogens from faecal samples of patients with community-acquired diarrhoea. Eur J Clin Microbiol Infect Dis 23, 529-534.

Amar, C. F., East, C. L., Grant, K. A., Gray, J., Iturriza-Gomara, M., Maclure, E. A. \&

McLauchlin, J. (2005). Detection of viral, bacterial, and parasitological RNA or DNA of nine intestinal pathogens in fecal samples 
Table 1. Strains of DEC submitted to GIRU between April and October 2009 and archive strains of E. coli $O 151$ and $O 62$ from 2004 to 2008

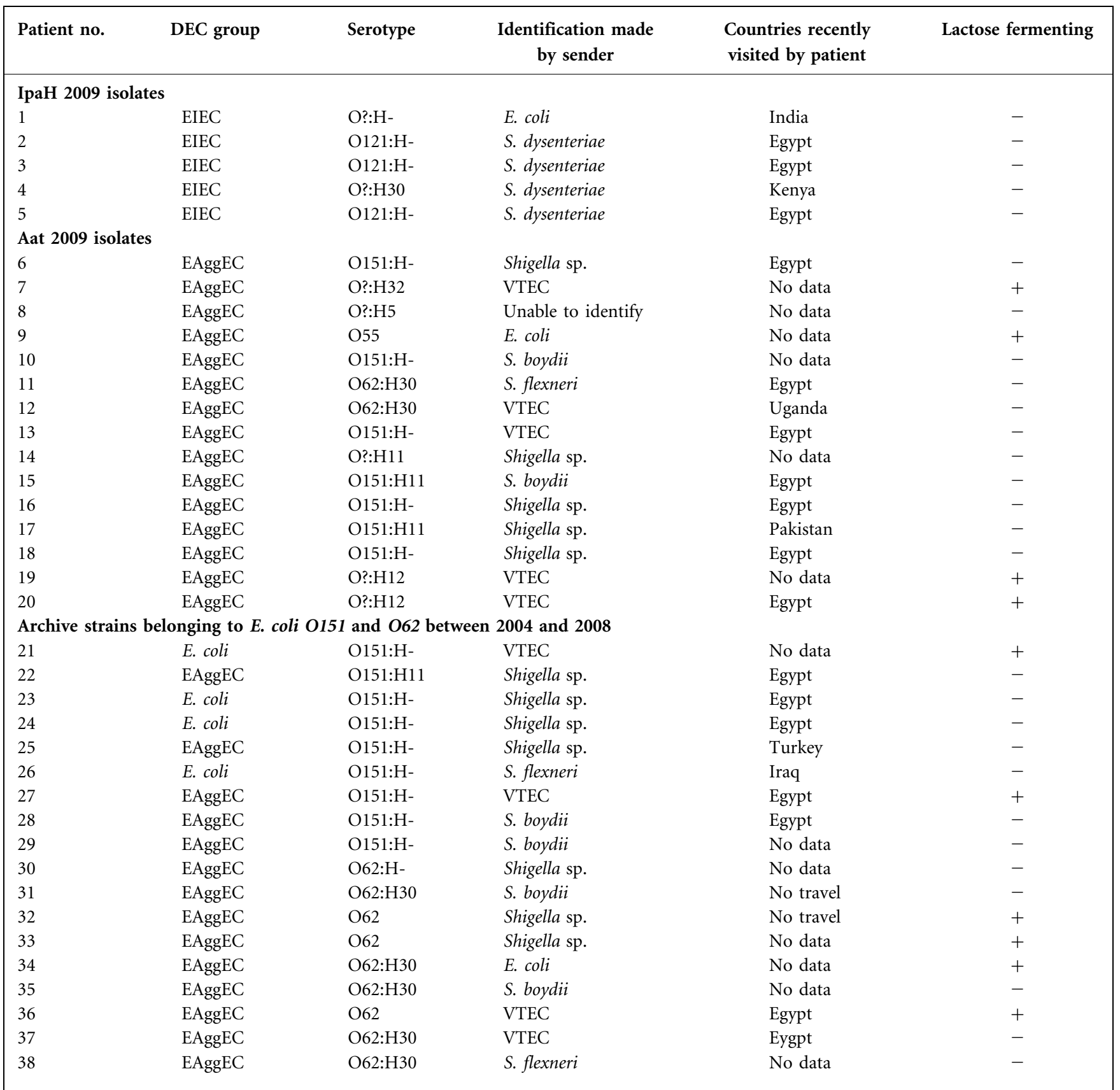

S., Shigella.

archived as part of the English infectious intestinal disease study: assessment of the stability of target nucleic acid. Diagn Mol Pathol 14, 90-96.

Barroe, G. I. \& Feltham, R. K. A. (editors) (2003). Characters of Gram-negative bacteria. In Cowan \& Steel's Manual for the Identification of Medical Bacteria. Cambridge: Cambridge University Press.
Baudry, B., Savarino, S. J., Vial, P., Kaper, J. B. \& Levine, M. M. (1990). A sensitive and specific DNA probe to identify enteroaggregative Escherichia coli, a recently discovered diarrheal pathogen. J Infect Dis 161, 1249-1251.

FSA (2000). Report of the Study of Infectious Intestinal Disease in England. Food Standards Agency. Norwich: The Stationery Office.
Jenkins, C., Tembo, M., Chart, H., Cheasty, T., Willshaw, G. A., Phillips, A. D., Tompkins, D. \& Smith, H. (2006). Detection of enteroaggregative Escherichia coli in faecal samples from patients in the community with diarrhoea. J Med Microbiol 55, 1493-1497.

Kaper, J. B., Nataro, J. P. \& Mobley, H. L. (2004). Pathogenic Escherichia coli. Nat Rev Microbiol 2, 123-140. 
Nataro, J. P., Kaper, J. B., Robins-Browne, R., Prado, V., Vial, P. \& Levine, M. M. (1987).

Patterns of adherence of diarrheagenic

Escherichia coli to HEp-2 cells. Pediatr Infect Dis J 6, 829-831.

Scheutz, F. \& Strockbine, N. (2007). Bergey's

Manual of Systematic Bacteriology, vol. 2. Edited by D. J. Brenner, N. R. Krieg \& J. T. Staley. New York: Springer Science.
Schmidt, H., Knop, C., Franke, S., Aleksic, S., Heesemann, J. \& Karch, H. (1995).

Development of PCR for screening of enteroaggregative Escherichia coli. J Clin Microbiol 33, 701-705.

Sethabutr, O., Venkatesan, M., Murphy, G. S., Eampokalap, B., Hoge, C. W. \& Echeverria, P. (1993). Detection of Shigellae and enteroinvasive Escherichia coli by amplification of the invasion plasmid antigen $\mathrm{H}$ DNA sequence in patients with dysentery. J Infect Dis 167, 458-461.

Tompkins, D. S., Hudson, M. J., Smith, H. R., Eglin, R. P., Wheeler, J. G., Brett, M. M., Owen, R. J., Brazier, J. S., Cumberland, P. \& other authors (1999). A study of infectious intestinal disease in England: microbiological findings in cases and controls. Commun Dis Public Health 2, 108-113. 